\title{
Sports Marketing in Nigeria: Governments' Funding and Sports Development Recommendations
}

\author{
Akarah, Emmanuel Oghenebrorien \\ Department of Physical \& Health Education, Delta State University, Abraka, Nigeria \\ E-mail: dedonspino@yahoo.co.uk
}

Doi:10.5901/ajis.2014.v3n1p279

\begin{abstract}
The Nigeria government has been identified as being the major proprietor of sports in terms of funding and administration. Policies have been formulated by the Nigeria government that are aimed at making the sports sector a contributory sector to her economy base. However, the policies which seek to use the Public-Private Partnership (PPP) model in the sector have not been implemented. Sports marketing in Nigeria depict the marketing of sports products and services directly to consumers of sports and on the other hand, entail the marketing of other consumer and industrial products or services through sports promotions. Sports marketing would be effective in Nigeria if sports activities are designed by the Nigeria sports sector to meet the sports needs and wants of sports consumers through exchange processes that are aimed at generating revenue that would develop sports and boost the Nigeria economy. The article identifies the conceptual model for effective sports marketing in Nigeria as a panacea for attaining the Vision 20:2020 through adopting and implementing the sports market mix in the sports sector with the active involvement of corporate and private organizations as well as other stakeholders.
\end{abstract}

Keywords: Sports Marketing, Effective Sports Marketing, Sports Market Mix, Sports Funding, Sports Development, Public-Private Partnership (PPP), Vision 20:2020.

\section{Introduction}

It would become important to note that over the years, Nigeria has been guided by well formulated policies for every of her designed programme with a view to achieving the set goals of such programmes. While most sectors of the Nigeria economy have been guided through this phase, the Nigeria government's first official policy guideline for the sports subsector was only formulated in 1989 (Aibueku,2002). The 1989, 2000 and 2009 sports development policies have no doubt been road maps for achieving sports development in Nigeria. The National Sports Policy (2009) particularly recognizes the need for Public-Private Partnership (PPP) as a way of further ensuring sports development especially against the backdrop that government alone cannot continue to fund sports and the need for the private sector to assist in developing sports through sports marketing strategies. Despite these lofty policies, the extent of implementation and result oriented outcomes are still some mirage. Perhaps, this was why Pfeffer (1992) noted that the failure to implement carefully conceived ideas and decisions is increasingly pervasive in both public and private organizations.

\section{Sports Marketing in Nigeria}

Sports marketing consist of all activities designed to meet the needs and wants of sports consumers through exchange processes. These could be the marketing of sports products and services directly to consumers of sports, and marketing of other consumer and industrial products or services through the use of sports promotions (Mullin, Hardy and Sutton, 2000; Shilbury, Quick and Westerbeek, 1998; Pitts, 1998). Akarah (2007) noted that sports marketing in Nigeria depict on the one hand, the marketing of sports products and services directly to the consumers of sports by sports goods manufacturers such as Nike, Adidas, Reebok, Puma and so on while on the other hand, it could be the marketing of other consumer and industrial products or services through the use of sports promotions as is the case when Pepsi-Cola, Coca-Cola, Cadbury, MTN, GLOBACOM and so on sponsor sports programmes thus advertising their firms or wares and further stated that sports marketing would be effective in Nigeria if sports activities are designed by the Nigeria sports sector to meet the sports needs and wants of sports consumers through exchange processes that are aimed at developing sports and generating revenue that will boost the Nigeria economy.

The Federal Republic of Nigeria Economic Transformation Blueprint on Nigeria Vision 20:2020 (2009) intends 
Nigeria to have a large, strong, diversified, sustainable and competitive economy that effectively harnesses the talents and energies of its people and responsibly exploits its natural endowments to guarantee a high standard of living and equality of its citizens by the year 2020. It also intends the Nigeria economy to grow at an average of $13.8 \%$ during the time horizon thus becoming a globally competitive economy that is resilient and diversified with a globally competitive manufacturing sector that is highly integrated and contributes no less than $20 \%$ Gross Domestic Product. It further noted that if well harnessed, sports have the potential to create business opportunities and employment, thereby enhancing income and reducing poverty.

The Vision 20:2020 seeks to stimulate domestic and foreign trade in value adding goods and services as well as foster strong linkages among all sectors of the economy through the production of textiles, wearing apparels and leather as part of the industrial prongs in stimulating the economy. In this regard, Akarah's (2012) conceptual model for effective sports marketing in Nigeria identified the role of sports goods manufacturers as part of the sports producers thus generating revenue for the Nigeria economy especially, as the regional, zonal and branch offices that would be set up would create employment opportunities as well as enhance the remittance of taxes and tariffs that will further help to boost the economy.

\section{Sports Administration in Nigeria}

The National Sports Policy (2009) and the Federal Republic of Nigeria (1997) report on Vision 2010 acknowledge that, sports administration and practice in Nigeria have taken a new dimension, thereby becoming a big commercial venture and employer of labour. However, the Federal Government of Nigeria through the National Sports Council in 1962 now renamed the National Sports Commission controls, regulates and promotes sports in Nigeria (National Sports Policy 2000, 2009; Federal Republic of Nigeria (1997) Vision 2010). Toward this end, Kienka (1990) and Akarah (2007) noted that while the Nigeria governments' monetary commitments towards the organization and administration of sports are very high, returns to government in terms of profit have not been commensurate.

\section{Sports Funding and Development}

The Nigeria government has been identified as being the major proprietor of sports in terms of funding and administration (National Sports Policy, 2009; Abone, 2003; Amuchie, 2003; Federal Republic of Nigeria, 1997; Kienka, 1990). The National Sports Policy (2009) includes the obligations of the three tiers of Government (Federal, State and Local Governments) amongst others to be; providing enabling legislation for sports, formulation and review of the National Sports Policy, development and maintenance of government sports facilities, creation of conducive environment for participation of sports, ensuring adequate budgetary allocations for sports, organizing and funding of researches in sports as well as ensuring that at least $5 \%$ of the total budget for sports is earmarked for maintenance of sports facilities and infrastructure.

The Nigeria government no doubt realizes the impact of funding towards sports development in Nigeria and notes that; the relatively high overhead costs associated with financing sports programmes, camping, training and competitions continue to hinder its development. Toward this end, the National Sports Policy (2009) notes that, it is necessary to encourage greater financial support for sporting activities. Therefore, the National Sports Commission, its agencies and affiliates shall amongst others seek to, offer incentives that would encourage financial assistance from the private sector for sports programmes, undertake fund raising programmes to enhance financing of their activities, encourage the private sector to contribute to developing sports.

It would be note worthy to mention that President Goodluck Jonathan identified poor and inadequate facilities and infrastructure, poor funding and poor sports administration as part of the dwindling sports fortunes in Nigeria (Bassey, 2012). Sports have become big business and as a result, government cannot solely continue to fund sports in Nigeria especially when in recent years, an array of cities throughout the world have incorporated sports events into their economic development mix (National Sports Policy, 2009; Amuchie, 2003; Aiyejuyo and Ayoade, 2002; Chalip and Leyns, 2002).

The National Sports Policy (2009) also identifies governments' understanding that facilities are major considerations and determinants of sports developments as, they provide standard settings for fitness, recreation and competition programmes. Toward this end, government in conjunction with stakeholders shall provide standard sports facilities and equipment at national, state and local government levels as well as ensure availability of sporting facilities in schools, communities and mass housing arena. Despite recognizing the role of stakeholders in sports development, 
Akarah (2007) noted that almost all the sporting facilities in Nigeria are owned by governments while maintaining them is recurring problem that has left them in sorry situations.

The impact of sports facilities in sports marketing cannot be under estimated as, the number and nature of sports facilities are the place (market) where the product (sports) are showcased if the product (sports) are to be appreciated and patronized by the consumers. Adeyanju (1986), Ojeme (1999) and Jeroh (2005) espoused that the provision of good and well equipped facilities are among the essential factors that are necessary for effective sports organization and administration in Nigeria. Studies have however revealed that most of the existing stadia in Nigeria are owned by governments just as the funding and administration have also been the prerogatives of government thus preventing the active involvement of the private sector despite the fact that government has opted to encourage development, management and maintenance of sporting infrastructure through Public-Private Partnership (PPP) model (Akarah, 2007; Jeroh, 2005; Amuchie, 2003; Abone, 2002; Ogunmola, 2002; Aiyejuyo and Ayoade, 2002; Kienka, 1990; Adeyanju, 1986).

\section{Recommendations}

It is a matter of necessity to ensure that there should be adequate publicity on the design, publication, presentation as well as the involvement of sports administrators in sports policy mandates so as to ensure that all concerned with implementation of such policies are well informed of their existence and characterization (Aibueku and Ogbouma, 2013). Sports no doubt, would aid in the attainment of the Vision 20:2020 goal if effective sports marketing in Nigeria is used as a parameter for generating revenue that would help to boost the Nigeria economy base through adopting and implementing the sports market mix in the sports sector with the active involvement of corporate and private organizations as well as other stakeholders (Akarah, 2007, 2009, 2010 ; National Sports Policy, 2009).

\section{Conclusion}

In light of the fact that the average Nigerian has a passion for sports whether for recreation or as competition, Akarah's (2012) conceptual model for effective sports marketing in Nigeria notes that, in order to improve the Nigeria economy base and the attainment of the Vision 20:2020 through the sports sector, government should provide an appropriate legal and regulatory environment for private capital investment as well as cultivate an effective technology transfer programme to fast-track local production of sports, recreation and entertainment equipment/facilities.

The Vision 20:2020 blueprint states that Nigeria currently ranks 158 out of 177 economies on the Human Development Index (HDR) despite her rich cultural endowment and abundant natural resources. It will therefore be apt for Nigeria to incorporate sports marketing into her economic development mix (Akarah, 2010a, 2010 ).

\section{References}

Abone, O. M. (2003, March). "Marketing and Sponsorship of Sports in Nigerian Schools." Anambra State Journal for Physical, Health Education, Recreation, Sport and Dance (ANJOPHER.SD). Vol. 1, No 1 Pp 95-104.

Adeyanju, F. B. (June 1986). "Psychological preparation of athletes for sports participation: Tips on coping with stress of competition." A paper presented at Sport Psychology Association of Nigeria (SPAN) Seminar, National Institute for Sports, Surulere, Lagos, in Jeroh, E. J. (2005): The role of incentives in sports performance among Nigerian University Students. Unpublished Ph. D Dissertation, Department of Science Education (Curriculum and Instruction Unit), Delta State University, Abraka.

Aibueku, S. O. (2000). Analysis of the implementation of Nigeria Sports Development Policy in grassroot institutions in Edo State. Unpublished Ph.D Dissertation, University of Benin, Benin City.

Aibueku, S. O. \& Ogbouma, S. (2013). Extent of implementation of the 2009 National Sports Policy of Nigeria: Implications for sports science, exercise science and sport medicine. Academic Research International. 2 (2), 541-549.

Aiyejuyo,L. and Ayoade, S. (May, 2002). "Politics in Sports Leadership: An Inherent Danger to Sports Development in Nigeria." Journal of Sports Management and Educational Research Vol 1, No 1 P147.

Akarah, E. O. (2007). Psychosocial and economic factors as predictors of effective sport marketing in Nigeria. Unpublished Ph. D Dissertation, Delta State University, Abraka.

Akarah, E. (2009). Professionalism in sports as predictor of effective sport marketing in Nigeria. Journal of Sports Psychology Association of Nigeria (JOSPAN). 5. 53-58. Awemark Publishers.

Akarah, E. (2010a). Economic environment as a predictor of effective sport marketing in Nigeria. Annals of Modern Education. 2 (1) 165172.

Akarah, E. (2010 b). Demographic, psychosocial and economic factors as predictors of effective sport marketing in Nigeria. Journal of Sports Psychology Association of Nigeria (JOSPAN). 6. 89-97. Awemark Publishers. 
Akarah, E. (2012). Conceptual model for effective sports marketing in Nigeria. African Research Review. 6 (1)24. 146-154

Amuchie, F. A. (2003). Pre-Colonial and Colonial Sports in Nigeria: Their Influence on Contemporary Sports Development in Nigeria. Sport in Contemporary African Society: An Anthology. South Africa, Dynasty Printers.

Bassey, P. (2012). President Jonathan promises changes in sports. Vanguard, October 23, p54.

Chalip, L. \& Leyns. A (2002) Local Business Leveraging of a Sport Event: Managing an Event for Economic Benefit. Journal of Sport Management ${ }_{1}$ 16.132. Human Kinetics Publishers, Inc.

Federal Republic of Nigeria (1997). Vision 2010. Report of the Vision 2010 Committee. Main Report.

Federal Republic of Nigeria (2009). National Sports Policy. Abuja, Yaliam Press Ltd.

Federal republic of Nigeria (2009). Nigeria Vision 20:2020 Economic Transformation Blueprint.

Jeroh, E. J. (2005). The role of incentives in sports performance among Nigerian University Students. Unpublished Ph. D Dissertation, Department of Science Education (Curriculum and Instruction Unit), Delta State University, Abraka.

Kienka, G. (1990). Sport Administration in Nigeria. Lagos, International Tennis Academy.

Mullin, B. J., Hardy, S. \& Sutton, W. A. (2000) 2nd ed: Sport Marketing. Champaign, Illinois, Human Kinetics Publishers.

Ogunmola, A. L. (May, 2002). "Sports in Nation Development." Journal of Sports Management and Educational Research Vol.1, No 1 Pp1-5.

Ojeme, E. O. (1999). "Ensuring the availability of standard sports facilities and equipment for the challenges of sports development." Proceedings of Seminar Organized by Federal Ministry of Sports and Social Development, Abuja. 24th - 26th August.

Pfeffer, J. (1992). Managing with power: Politics and organizations. Boston, Havard Business School Press.

Pitts, B. (1998). Case Studies in Sport Marketing. Morgantown, WV, Fitness Information Technology.

Shilbury, D., Quick, S. \& Westerbeek, H. (1998). Strategic Sport Marketing. St. Leonards NSW, Allen and Unwin. 